\title{
Colonic Dysmotility in Murine Partial Colonic Obstruction Due to Functional Changes in Interstitial Cells
}

\author{
Qianqian Wang, ${ }^{1,2}$ Jingyu Zang, ${ }^{1,2}$ Xu Huang, ${ }^{3}$ Hongli Lu, ${ }^{3}$ Wenxie $\mathrm{Xu}^{1,3}$ and Jie Chen ${ }^{1,2 *}$ \\ ${ }^{1}$ Department of Pediatric Surgery, Xinhua Hospital Affiliated to Shanghai Jiaotong University School of Medicine, Shanghai, China; ${ }^{2}$ Department \\ of Pediatric Surgery, Jiaxing Maternity and Child Health Care Hospital, Jiaxing; China; and ${ }^{3}$ Department of Anatomy and Physiology, Shanghai \\ Jiaotong University School of Medicine, Shanghai, China
}

\section{Background/Aims}

Interstitial cells play important roles in gastrointestinal (GI) neuro-smooth muscle transmission. The underlying mechanisms of colonic dysmotility have not been well illustrated. We established a partial colon obstruction (PCO) mouse model to investigate the changes of interstitial cells and the correlation with colonic motility.

\section{Methods}

Western blot technique was employed to observe the protein expressions of Kit, platelet-derived growth factor receptor- $\alpha$ (Pdgfra), $\mathrm{Ca}^{2+}$-activated $\mathrm{Cl}^{-}$(Ano1) channels, and small conductance $\mathrm{Ca}^{2+}$ - activated $\mathrm{K}^{+}(\mathrm{SK})$ channels. Colonic migrating motor complexes (CMMCs) and isometric force measurements were employed in control mice and PCO mice.

\section{Results}

PCO mice showed distended abdomen and feces excretion was significantly reduced. Anatomically, the colon above the obstructive silicone ring was obviously dilated. Kit and Ano1 proteins in the colonic smooth muscle layer of the PCO colons were significantly decreased, while the expression of Pdgfra and SK3 proteins were significantly increased. The effects of a nitric oxide synthase inhibitor (L-NAME) and an Ano1 channel inhibitor (NPPB) on CMMC and colonic spontaneous contractions were decreased in the proximal and distal colons of PCO mice. The SK agonist, CyPPA and antagonist, apamin in PCO mice showed more effect to the CMMCs and colonic smooth muscle contractions.

\section{Conclusions}

Colonic transit disorder may be due to the downregulation of the Kit and Ano1 channels and the upregulation of SK3 channels in platelet-derived growth factor receptor- $\alpha$ positive $\left(\mathrm{PDGFR}^{+}\right)$cells. The imbalance between interstitial cells of Cajal-Ano1 and PDGFR $\alpha$ SK3 distribution might be a potential reason for the colonic dysmotility.

(J Neurogastroenterol Motil 2019;25:589-601)

\section{Key Words}

Chloride channels; Interstitial cells of Cajal; Small-conductance calcium-activated potassium channels

Received: July 13, 2019 Revised: August 7, 2019 Accepted: August 27, 2019

(a) This is an Open Access article distributed under the terms of the Creative Commons Attribution Non-Commercial License (http://creativecommons. org/licenses/by-nc/4.0) which permits unrestricted non-commercial use, distribution, and reproduction in any medium, provided the original work is properly cited.

${ }^{*}$ Correspondence: Jie Chen, MD, PhD

Department of Pediatric Surgery, Xinhua Hospital Affiliated to Shanghai Jiaotong University School of Medicine, 1665 Kongjiang Road, Shanghai 200092, China

Tel: +86-21-25078999, Fax: +86-21-25078999, E-mail: jiechen1974@163.com

Qianqian Wang and Jingyu Zang contributed equally to this work. 


\section{Introduction}

Gastrointestinal (GI) smooth muscles are composed of 3 types of cells, including smooth muscle cells, interstitial cells of Cajal (ICC), and platelet-derived growth factor receptor- $\alpha$ positive $\left(\mathrm{PDGFR} \alpha^{+}\right.$) cells, which is called the smooth muscle cells, ICC, and PDGFR $\alpha+$ cells (SIP) syncytium. ${ }^{1-3}$

Myenteric ICCs (ICC-MY) have a pacemaker role to generate spontaneous electrical activity. ${ }^{4}$ Calcium activated chloride channels (Ano 1, a molecular candidate) are highly expressed in ICCs and may be a candidate conductance of pacemaker potentials. ${ }^{4,5}$ Intramuscular ICCs (ICC-IM) display close anatomical apposition to nerve varicosities. ${ }^{6}$ ICC-IM respond to excitatory and inhibitory neurotransmitters between neurons and smooth muscles. ${ }^{6}$ Acetylcholine, which is a major excitatory neurotransmitter induced depolarization by activation of Anol currents. The effect of nitric oxide (NO), an inhibitory neurotransmitter, is also mediated by ICCIM, however the ionic conductance activated or inhibited by $\mathrm{NO}$ has not been clarified.

PDGFR $\alpha^{+}$cells were identified in the muscle layers of the GI tract and showed close apposition with enteric motor neurons. ${ }^{7}$ These cells are mainly distributed in the muscle layers of murine and human colon and mediate purinergic inhibitory neurotransmission. ${ }^{7,8}$ PDGFR $\alpha^{+}$cells uniquely express the purinergic P2Y1 receptor and small-conductance $\mathrm{Ca}^{2+}$-activated $\mathrm{K}^{+}$channels (a molecular candidate Kcnn3, SK3) which are mainly responsible conductance for purines released from inhibitory enteric motor neurons. ${ }^{9}$ Activation of SK channels in PDGFR $\alpha^{+}$cells induces hyperpolarization. ${ }^{8}$

Our previous study has shown that the density of ICC distribution was different from proximal and distal colons. ICCs are highly distributed in the proximal colon than in the distal colon. In contrast, density of $\mathrm{PDGFR}^{+}$cells in the distal colon is higher compared to the proximal colon. ${ }^{10}$ However, there is no clear description on the role of this different cellular distribution on colonic motility including colonic migrating motor complex (CMMC).

The mechanisms of colonic dysmotility in partial colon obstruction (PCO) is not fully clarified. In previous studies, obstructed animal models and patients with idiopathic chronic pseudo-obstruction showed a decreased density of the ICC. ${ }^{11-14}$ In the study of murine proximal colon, PCO did not affect ICC density on days 1 and 3. However, the ICC network was disrupted on day 7 of PCO. ${ }^{15}$ These data suggested that partial loss of ICC may be associated with colonic dysmotility. However, besides studies of morphological changes, the mechanisms of functional alteration in the PCO colon have not been studied.

In the present study, we established a murine PCO model to investigate the changes in protein expression of Kit, platelet-derived growth factor receptor- $\alpha$ (Pdgfra), Ano1, and SK3 channels using western blotting. We also examined the functional alteration in $\mathrm{PCO}$ mice by measuring colonic CMMCs and isometric force measurements.

\section{Materials and Methods}

\section{Ethics Statement}

This study was performed in compliance with the recommendations in the Guide for the Care and Use of Laboratory Animals of the Science and Technology Commission of P.R.C. (STCC Publication No. 2, revised 1988). The protocol followed the instructions by the Committee on the Ethics of Animal Experiments (Permit No. Hu 686-2009).

\section{Animal Model}

Male specific pathogen-free (SPF) C57BL/6 mice aged 5-6 weeks with body weights of $20 \pm 4 \mathrm{~g}$ were used (Shanghai SLAC Laboratory Animal Co, Shanghai, China). The mice were housed under $22-24^{\circ} \mathrm{C}$ (12 hour- light and 12-hour dark cycle), with free access to food and water. PCO mouse model was prepared by the following procedures. The mice were fasted for 6 hours before surgery, and then were anesthetized with $2 \%$ isoflurane inhalation. A midline laparotomy was performed on the mice. A silicon ring (4 mm x $4 \mathrm{~mm}, 3 \mathrm{~mm}$ internal diameter) was applied to the distal colon $3 \mathrm{~cm}$ proximal to the end of the murine colon. After surgery, all efforts were made to minimize suffering, including analgesic medications and put the mice in a $35^{\circ} \mathrm{C}$ water bath. The mice were kept for 7 days until euthanasia. Monitoring was kept for weight, fecal pellets, and mental condition of the postoperative mice every day. Experiments were performed with the murine colons 7 days after surgery. The mice were euthanized with $2 \%$ isoflurane and sacrificed by cervical dislocation. The colon tissue from the ileocecal valve to the distal colon of obstruction was removed and pinned to the base of a Sylgard silicone elastomer dish containing oxygenated $\left(95 \% \mathrm{O}_{2}\right.$ and $\left.5 \% \mathrm{CO}_{2}\right)$ Krebs solution.

\section{Western Blot Analysis}

Protein samples were harvested from colonic smooth muscle and homogenized in ice-cold RIPA buffer (1:10; P0013; Beyotime Chemical Co, Jiangsu, China) and $1 \%$ protease inhibitor cocktail 
(P2714; Sigma Aldrich, County Wicklow, Ireland). The homogenates were centrifuged at $12000 \mathrm{rpm}$ for 15 minutes at $4^{\circ} \mathrm{C}$. The supernatant collection and protein extraction were described previously. In brief, primary antibodies were incubated overnight at $4^{\circ} \mathrm{C}$ and secondary antibodies at room temperature for 2 hours. An antiPdgfro antibody $(1: 1000 ; 3174$; Cell Signaling Technology, Danvers, MA, USA), anti-SK3 antibody (1:500; ab28631; Abcam, Cambridge, UK), anti-Kit antibody (1:1000; 3074; Cell Signaling Technology), anti-Ano1 antibody (1:1000; ab191040; Abcam), anti- glyceraldehyde-3-phosphate dehydrogenas antibody (1:1000; GB11002; Servicebio, Wuhan, China), and HRP-linked antirabbit antibody (1:1000; 7074; Cell Signaling Technology) were used.

\section{CMMC Experiments}

Mice were sacrificed with overdose isoflurane inhalation followed by cervical dislocation. The whole colon was extracted from the body and carefully dissected to remove mesentery and fat tissues. All fecal materials were carefully expelled with repeated injection of Krebs solution. A glass capillary tube was inserted through the empty lumen to fix the colon segment to the dish floor. The colon segment was perfused with warm Krebs solution $\left(37^{\circ} \mathrm{C}, 5 \%\right.$ $\mathrm{CO}_{2}$ and $95 \% \mathrm{O}_{2}$ ) and stabilized for 30-40 minutes to recover colonic contraction activity. Silk thread (USP 5/0) was applied to proximal and distal parts of the colon to connect force transducers. The CMMC activity was recorded by an isometric force transducer (RM6240C; Chengdu Instrument Factory, Chengdu, China).

\section{Spontaneous Contractions of Smooth Muscle}

The mice were sacrificed as described above. The mucosa and submucosa layers were removed by fine dissecting scissors under a microscope. The smooth muscle strips $(8 \mathrm{~mm} \times 2 \mathrm{~mm}$ ) were cut along the circular axis. A force transducer (RM6240C; Chengdu) was used for contractions along the longitudinal axis in $10 \mathrm{~mL}$ organ baths with $37^{\circ} \mathrm{C}$ oxygenated $\left(95 \% \mathrm{O}_{2}\right.$ and $\left.5 \% \mathrm{CO}_{2}\right)$ Krebs solution. Krebs solution was recycled every 20 minutes. The area under the curve (AUC) was calculated by adjustment of resting tension to baseline in control traces. Spontaneous contractions for 2 minute recordings and CMMC for 10 minutes recordings were used for analysis. AUC was normalized to control to compare with effects of drugs.

\section{Solutions and Drugs}

The Krebs solution: $\mathrm{NaCl}, 118.5 \mathrm{mM} ; \mathrm{KCl}, 4.5 \mathrm{mM} ; \mathrm{MgCl}_{2}$, $1.2 \mathrm{mM} ; \mathrm{NaHCO}_{3}, 23.8 \mathrm{mM} ; \mathrm{KH}_{2} \mathrm{PO}_{4}, 1.2 \mathrm{mM}$; glucose 11.0
$\mathrm{mM}$; and $\mathrm{CaCl}_{2}, 2.4 \mathrm{mM}$. NG-Nitro-l-arginine methyl ester hydrochloride (L-NAME), 5-Nitro-2-(3-phenylpropylamino) benzoic acid (NPPB), Apamin and CyPPA were purchased from Tocris Bioscience (Ellisville, MO, USA).

\section{Statistical Methods}

Data are shown as the mean \pm SEM. Student's unpaired $t$ test was carried out to compare statistical significance in groups. Differences at $P<0.05$ level were considered statistically significant. $\mathrm{N}$ values represent the number of animals used in the experiments. Data analysis was performed with GraphPad Prism 6.0 (GraphPad Software, La Jolla, CA, USA).

\section{Results}

\section{Anatomic and Histological Changes in PCO Mice}

Distended abdomen was detected on the 7th day after surgery, with the absence of fecal pellet production. The colon was obviously distended, and large amounts of feces accumulated above the ring (Fig. 1A). The colon tissue in the proximal dilated segment $(>2 \mathrm{~cm})$ and the distal segment $(<2 \mathrm{~cm})$ from the inserted ring was dissected and analyzed by hematoxylin \& eosin (HE) staining (Fig. 1B), and the results showed that the smooth muscle layer was hypertrophied. The weight of the colonic smooth muscle layers in PCO mice increased significantly after removing the mucosa (Fig. 1C). The average thickness of the smooth muscle layer in control and PCO mice was significantly different (Fig. 1D).

\section{The Alteration of ICCS and Ano1 in Hypertrophic Colonic Smooth Muscle Layers}

To determine the remodeling of ICCs due to PCO, western blot approach was used to examine the expression of Kit and Ano1. We explored the density of Kit and Ano1 protein expression in the colonic smooth muscle tissues. Kit expression was higher in the proximal colon than in the distal colon (Fig. 2A). In the comparison of Kit in $\mathrm{PCO}$ and control colons, Kit in PCO was decreased to 0.48 \pm 0.12 compared to control mice $(3.24 \pm 0.45)$ in the proximal colon and to $0.61 \pm 0.14$ compared to control mice $(1.79 \pm 0.26)$ in the distal colon $\left({ }^{*} \mathrm{P}<0.05, \mathrm{n}=6\right.$; Fig. $2 \mathrm{~A}$ and $\left.2 \mathrm{C}\right)$. Similarly, Ano1 expression was slightly lower in the distal colon compared to the proximal colon. In PCO colon, Ano1 was downregulated to 1.06 \pm 0.20 compared to control $(1.73 \pm 0.35)$ in the proximal colon and to $0.85 \pm 0.11$ compared to control $(1.34 \pm 0.15)$ in the distal colon $\left({ }^{\star} P<0.05, \mathrm{n}=6\right.$; Fig. 2B and 2D). 

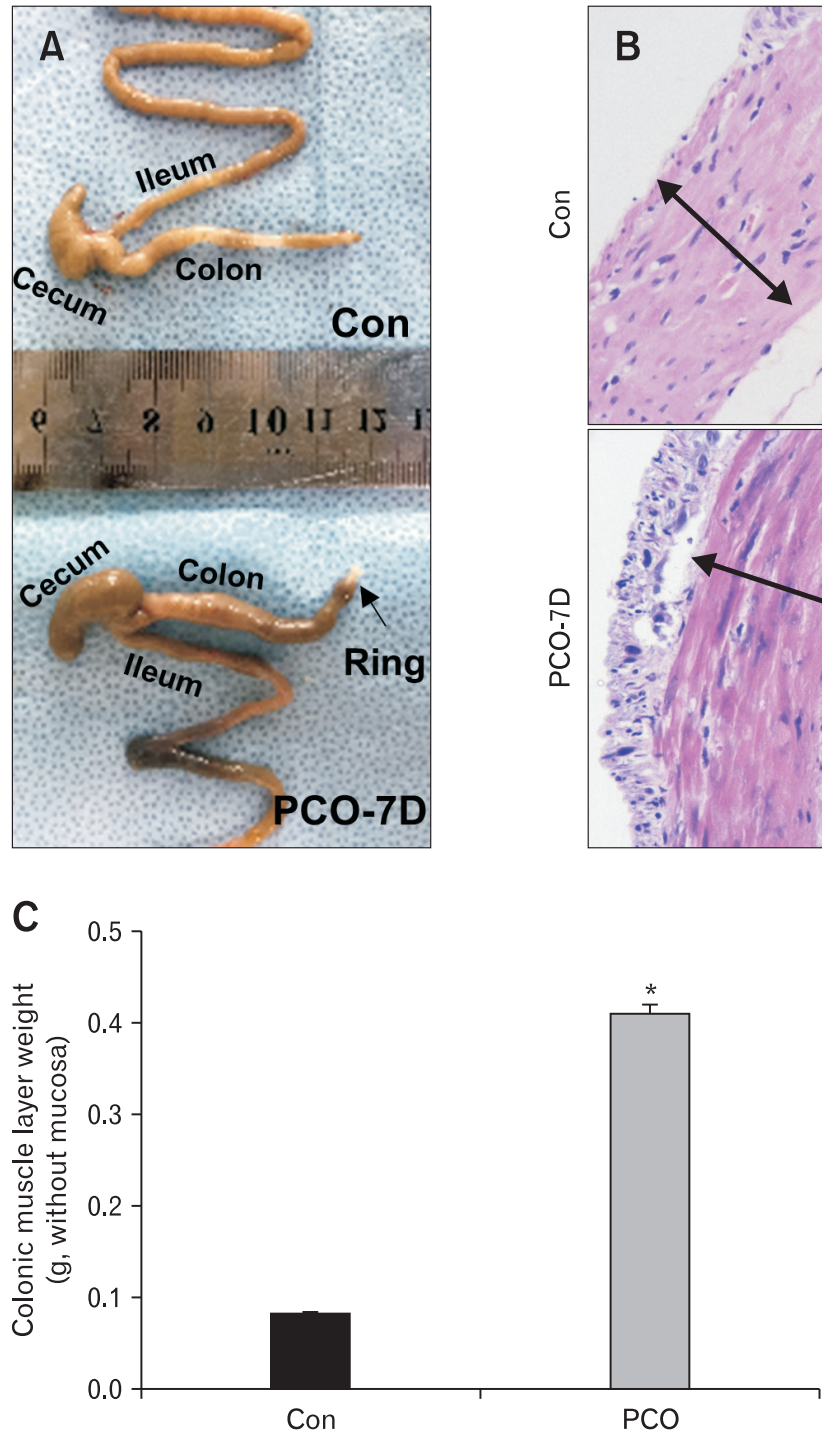
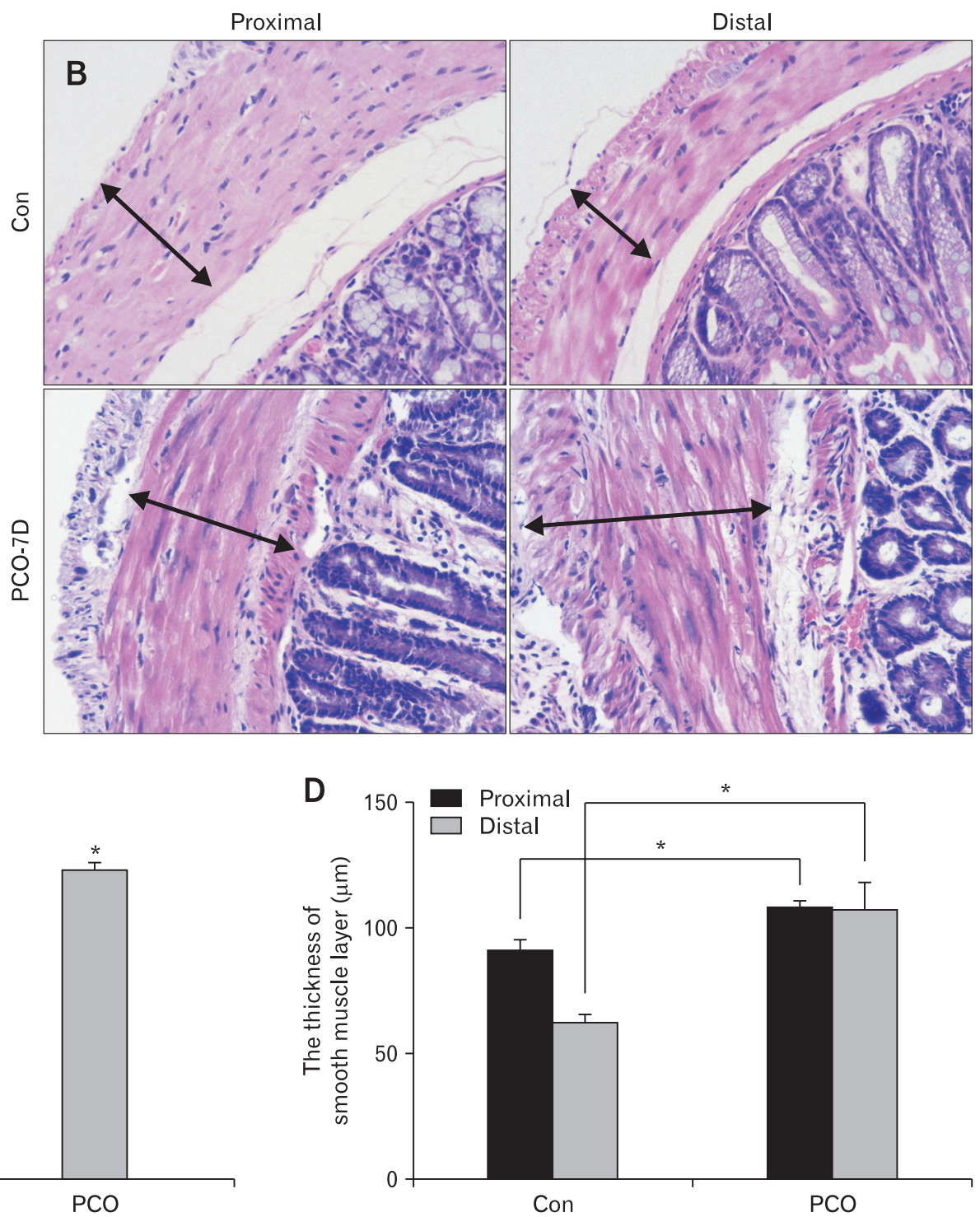

Figure 1. Surgically induced partial colon obstruction (PCO) in a mouse model. (A) Pictures showing the anatomic changes in control (Con) and PCO mice. (B, D) Comparison of the thickness of the smooth muscle layer between control and PCO mice by H\&E staining $(\times 200$ magnification) and statistical analysis $\left({ }^{*} P<0.05, \mathrm{n}=7\right)$. (C) Summarized data showing the colonic muscle layer weight in control and PCO mice $\left({ }^{*} P<0.05\right.$, $\mathrm{n}=7$ ).

\section{The Responses of Colonic Smooth Muscle to L-NAME and NPPB}

To observe the remodeling of ICCs and Anol channels in control and PCO colons, the effects of the NO synthase inhibitor LNAME and the Ano1 channel inhibitor NPPB on CMMC were examined using whole colons and muscle strips.

L-NAME $(100 \mu \mathrm{M})$ significantly enhanced the area under the curve (AUC) values of CMMCs. L-NAME increased the AUC of the proximal colon increased to $158.7 \pm 6.5 \%$ in control mice and $113.6 \pm 6.5 \%$ in the PCO mice $\left({ }^{*} P<0.05, \mathrm{n}=5\right.$; Fig. $3 \mathrm{~A}-\mathrm{C})$. In the distal colon, the corresponding AUC values also increased to $114.6 \pm 7.6 \%$ and $111.2 \pm 2.0 \%\left({ }^{\star} P<0.05, \mathrm{n}=\right.$ 5; Figure $3 \mathrm{~A}, \mathrm{~B}$ and D). However, the effectiveness of L-NAME was significantly decreased in PCO compared to control $\left({ }^{\#} \mathrm{P}<\right.$ 0.05 in proximal colons, ${ }^{\#} P<0.05$ in distal colons; Fig. $3 \mathrm{C}$ and 3D). To evaluate the function of Ano1 channel, NPPB ( $5 \mu \mathrm{M})$ was applied. The colonic transmission in the proximal colon was reduced to $46.2 \pm 1.8 \%$ in the control mice and $57.5 \pm 3.4 \%$ in the PCO mice ( ${ }^{\star} \mathrm{P}<0.05, \mathrm{n}=5$; Fig. $\left.3 \mathrm{E}-\mathrm{G}\right)$. In the distal colon, 
A

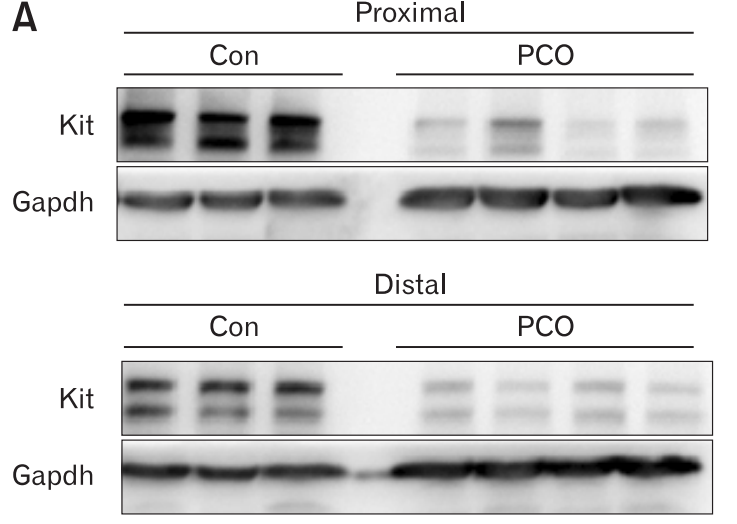

B $145 \mathrm{kD}$

$34 \mathrm{kD}$

$145 \mathrm{kD}$

$120 \mathrm{kD}$

$34 \mathrm{kD}$

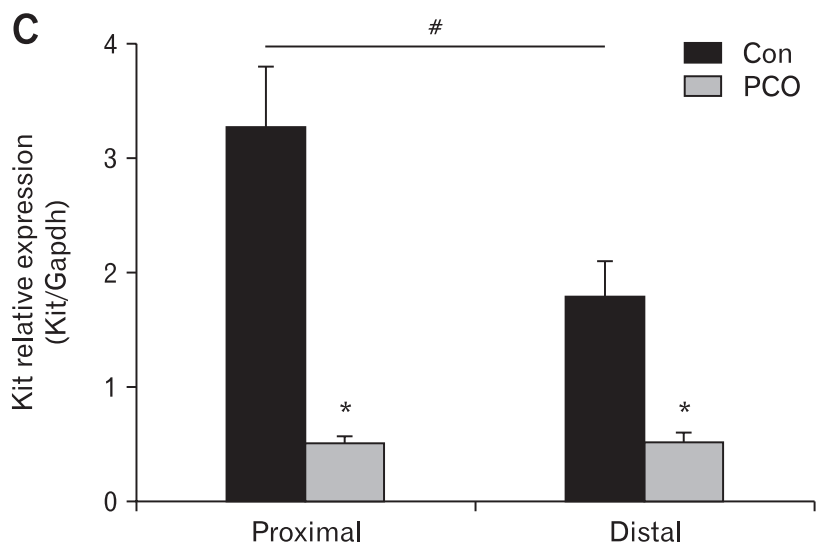

B

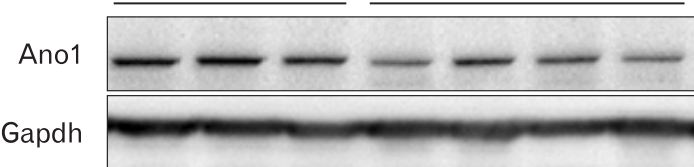

$114 \mathrm{kD}$

$34 \mathrm{kD}$

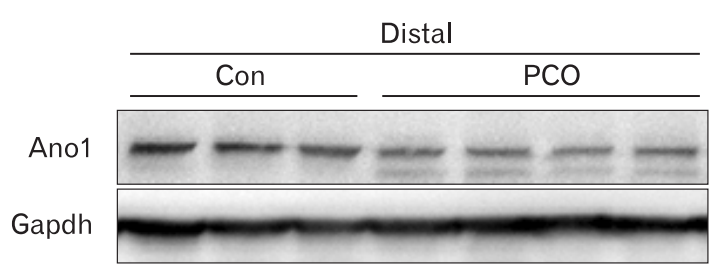

$114 \mathrm{kD}$

$34 \mathrm{kD}$

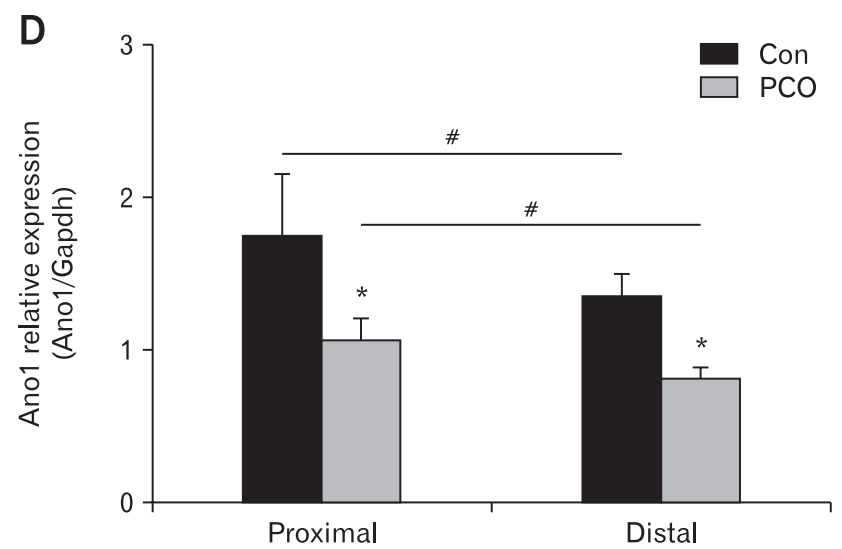

Figure 2. Expression of Kit and Ano1 in the colonic muscle layers of control (Con) and partial colon obstruction (PCO) mice. Western blot analysis of Kit (A) and Ano1 (B) in control and PCO mice. (C, D) The data were analyzed using densitometric quantification by Quantity One (\% glyceraldehyde-3-phosphate dehydrogenase [Gapdh], normalized to data from control mice; $\mathrm{n}=6$, ${ }^{*} P<0.05$, PCO vs control, ${ }^{\#} P<0.05$ proximal vs distal).

the CMMC transmission was reduced to $84.2 \pm 2.9 \%$ and 91.4 $\pm 2.1 \%$, respectively $\left({ }^{\star} \mathrm{P}<0.05, \mathrm{n}=5\right.$; Fig. $3 \mathrm{E}, 3 \mathrm{~F}$, and $\left.3 \mathrm{H}\right)$. NPPB showed less effect on CMMCs in PCO compared to control $\left({ }^{\#} P<0.05\right.$ in proximal colons, ${ }^{\#} P<0.05$ in distal colons; Fig. $3 \mathrm{G}$ and $3 \mathrm{H})$.

The effects of L-NAME and an Anol blocker to colonic muscle spontaneous contraction were investigated. L-NAME remarkably strengthened spontaneous contractions of the proximal colon in controls to $137.9 \pm 3.9 \%\left({ }^{*} P<0.05, \mathrm{n}=5\right.$; Fig. $4 \mathrm{~A}$ and $4 \mathrm{C})$, and in PCO mice to $119.9 \pm 5.5 \%\left({ }^{*} \mathrm{P}<0.05, \mathrm{n}=5\right.$; Fig. $4 \mathrm{~A}$ and $4 \mathrm{C})$. In the distal colon, AUC after L-NAME were also enhanced to $119.5 \pm 4.1 \%\left({ }^{\star} P 0.05, \mathrm{n}=5\right.$; Fig. $4 \mathrm{~B}$ and $\left.4 \mathrm{D}\right)$ in control and $110.2 \pm 10.7 \%\left({ }^{*} P<0.05, \mathrm{n}=5\right.$; Fig. $4 \mathrm{~B}$ and 4D) in PCO, respectively. However, the effect of L-NAME was significantly decreased in PCO mice compared to the control mice ( ${ }^{\#} P<0.05$ in proximal colons, ${ }^{\#} \mathrm{P}<0.05$ in distal colons; Fig. $4 \mathrm{C}$ and $4 \mathrm{D})$. NPPB decreased the AUC of spontaneous contractions to $48.9 \pm 6.7 \%$ vs $67.0 \pm 9.5 \%$ in the proximal colon (control vs PCO mice, $\mathrm{n}=5, \mathrm{P}<0.05$; Fig. $4 \mathrm{E}$ and $4 \mathrm{G}$ ) and $66.5 \pm 3.9 \%$ vs $80.0 \pm 4.1 \%$ in the distal colon (control vs PCO mice, $\mathrm{n}=5$, $P<0.05$; Fig. $4 \mathrm{~F}$ and $4 \mathrm{H})$. However, the inhibitory effects of NPPB were decreased in the PCO murine colon smooth muscle compared to control mice $\left({ }^{\#} \mathrm{P}<0.05\right.$ in proximal colons, ${ }^{\#} \mathrm{P}<$ 0.05 in distal colons; Fig. $4 \mathrm{G}$ and $4 \mathrm{H})$. Therefore, it was indicated that $\mathrm{NO}$ contributed significantly to the regulation of CMMC frequency, and ICCs and Anol channels may be downregulated in PCO mice in both the proximal and distal colons.

\section{The Alteration of PDGFR $\alpha^{+}$Cells and SK3 in Hypertrophic Colonic Smooth Muscles}

The western blot showed that the expression levels of Pdgfra protein were much higher in the PCO colon compared to those in control mice ( ${ }^{\star} \mathrm{P}<0.05, \mathrm{n}=6$; Fig. $5 \mathrm{~A}$ and $\left.5 \mathrm{C}\right)$. In the control group, the relative expression rates were $0.68 \pm 0.09$ in the proxi- 
A Con
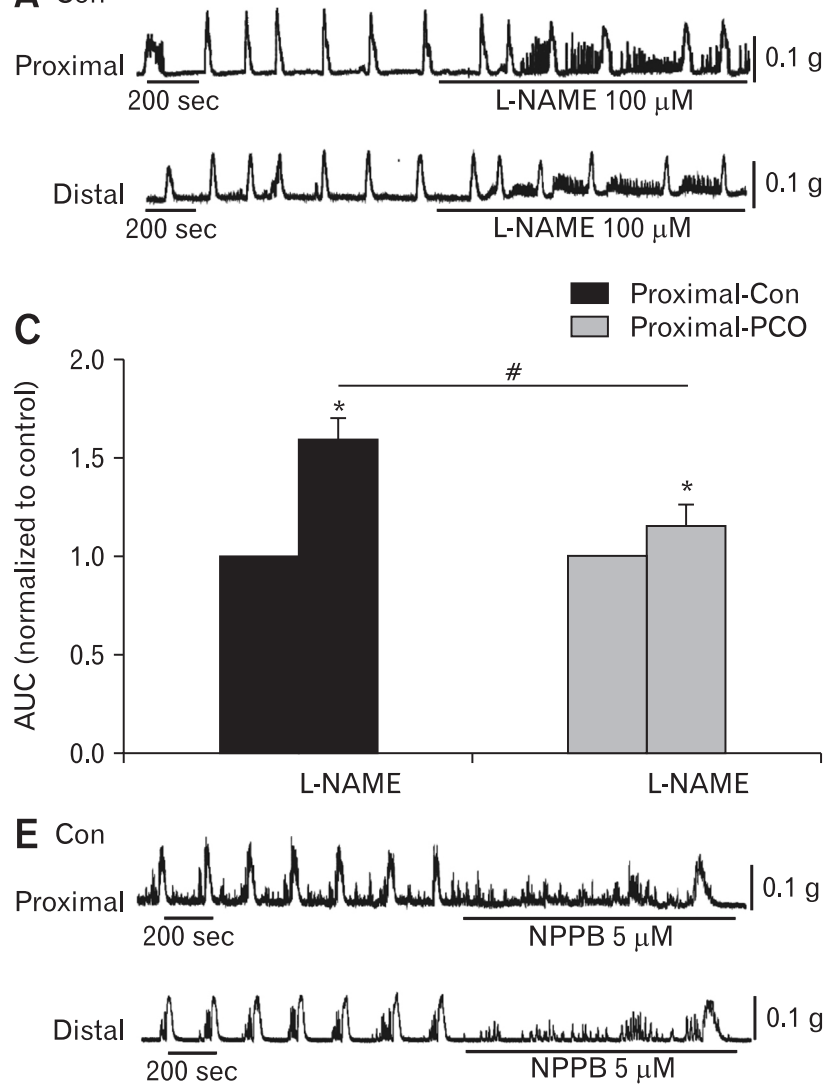

G

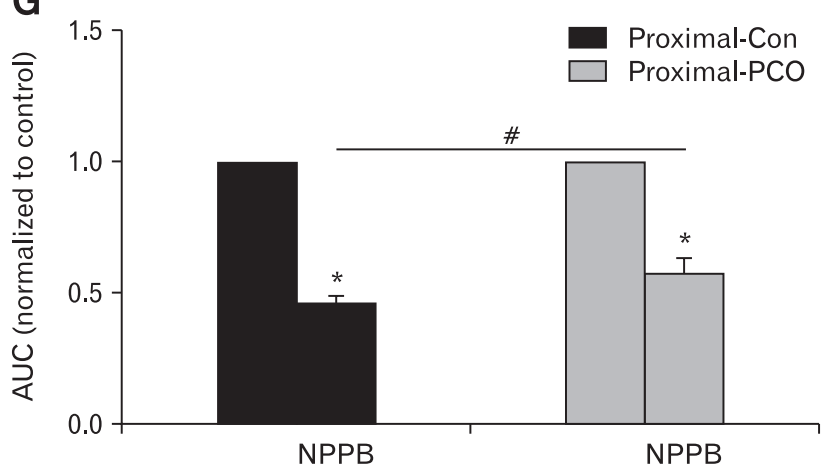

B PCO
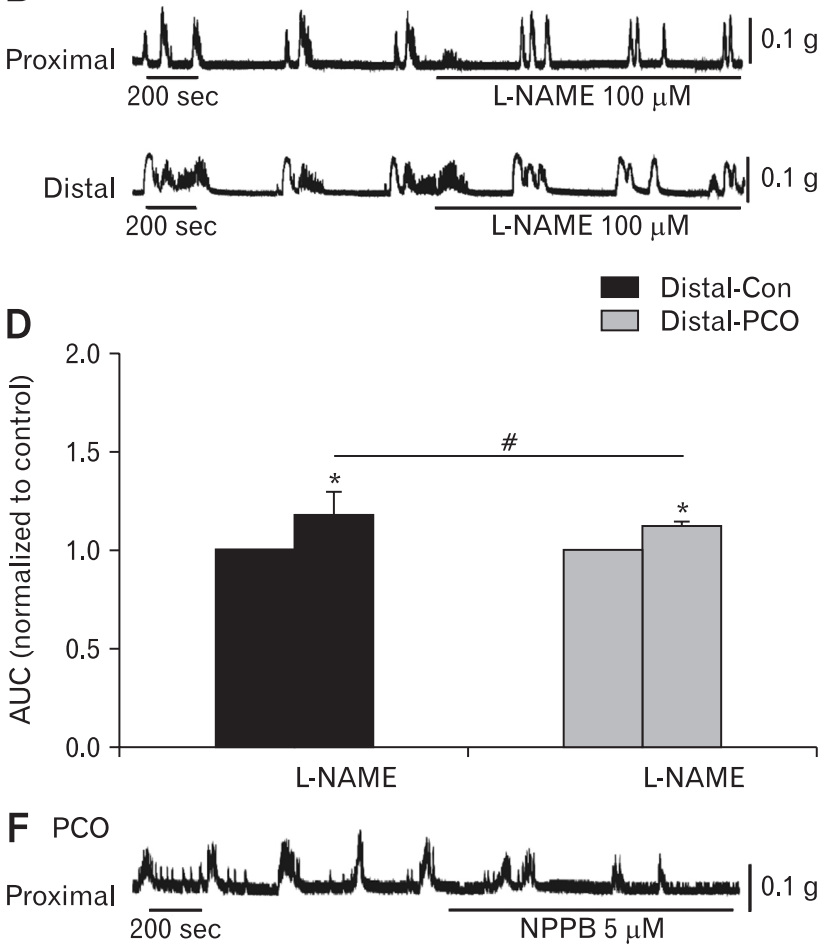

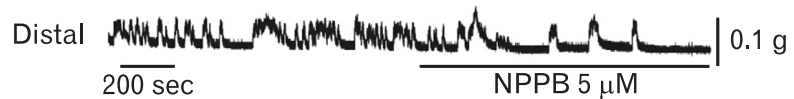

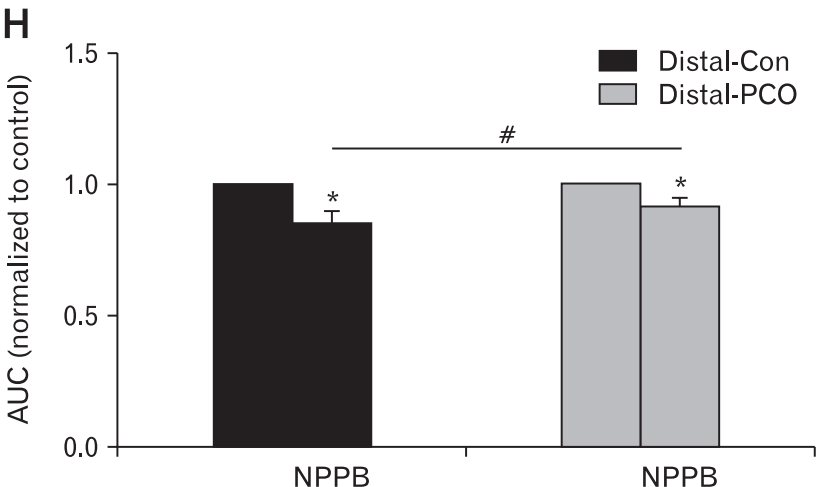

Figure 3. Effects of inhibitors of nitric oxide synthase (NOS) and $\mathrm{Ca}^{2+}$-activated $\mathrm{Cl}^{-}$channel (Ano1) on colonic migrating motor complexes (CMMCs) in the colonic muscles of control (Con) and partial colon obstruction (PCO) mice. (A, B) The inhibitory effects of NG-Nitro-l-arginine methyl ester hydrochloride (L-NAME; $100 \mu \mathrm{M}$ ) on CMMCs in the proximal and distal colons of both control and PCO mice. (C, D) The area under the curve (AUC) were normalized to the control (before the application of L-NAME) $\left(\mathrm{n}=5 ;{ }^{*} P<0.05, \mathrm{~L}-\mathrm{NAME}\right.$ vs control; ${ }^{*} P$ $<0.05$, PCO vs control mice). (E, F) Response of CMMCs to 5-Nitro-2-(3-phenylpropylamino) benzoic acid (NPPB; $5 \mu M$ ) in the proximal and distal colons in both control and PCO mice. $(\mathrm{G}, \mathrm{H})$ Summary of the response of CMMCs to NPPB in colonic muscles of control and PCO mice. The data were normalized to the control value (before the application of NPPB) $\left(\mathrm{n}=5 ;{ }^{*} \mathrm{P}<0.05, \mathrm{NPPB}\right.$ vs control; ${ }^{\#} \mathrm{P}<0.05, \mathrm{PCO}$ vs control mice).

mal colon and $1.28 \pm 0.93$ in the distal colon $\left({ }^{\#} P<0.05, \mathrm{n}=6\right.$; Fig. $5 \mathrm{~A}$ and $5 \mathrm{C}$ ). In the $\mathrm{PCO}$ group, the relative expression rates were $1.35 \pm 0.08$ in the proximal segment and $2.50 \pm 0.25$ in the distal segment $\left({ }^{\#} \mathrm{P}<0.05, \mathrm{n}=6\right.$; Fig. 5A and 5C). The expression of SK3 protein was higher in the PCO murine proximal and distal colon compared with those in control mice $\left({ }^{\star} P<0.05, \mathrm{n}=6\right.$; 
A Proximal

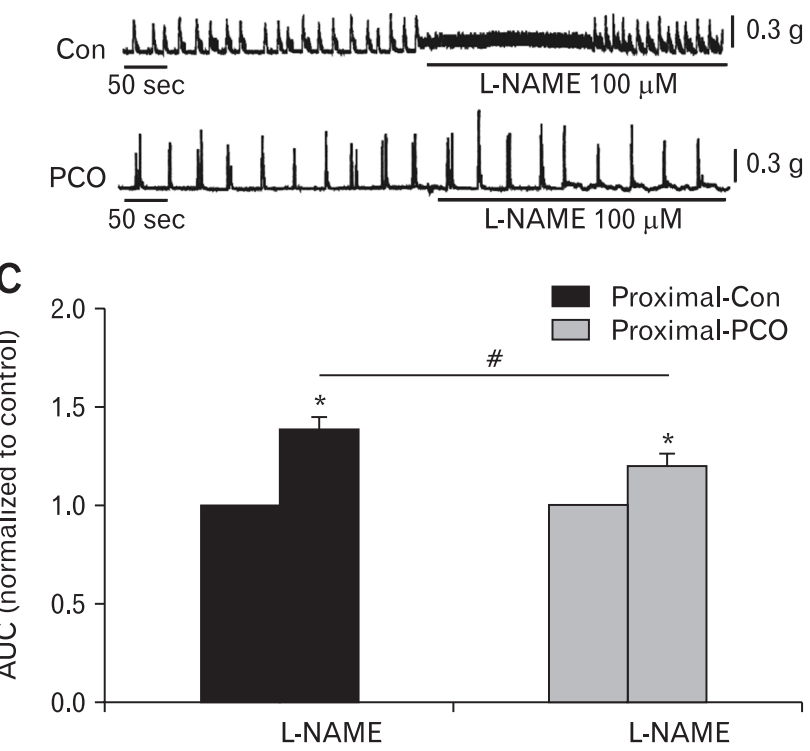

E Proximal

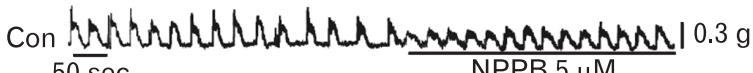

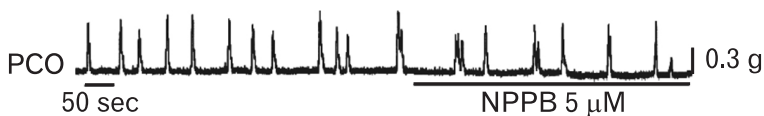

G

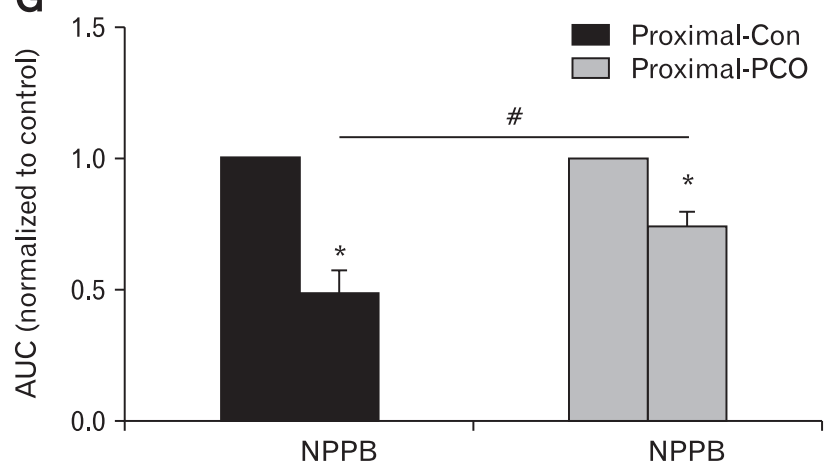

B Distal

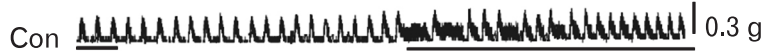
$50 \mathrm{sec} \quad$ L-NAME $100 \mu \mathrm{M}$
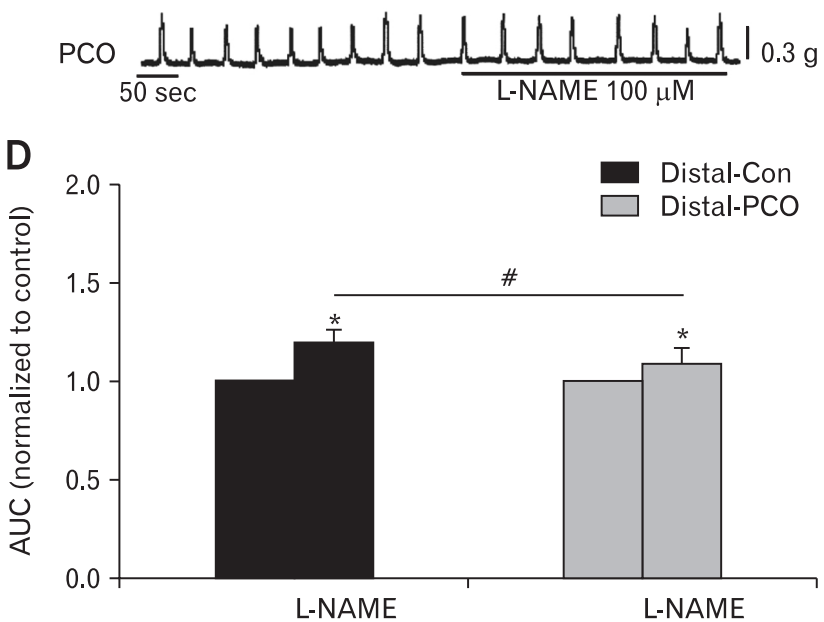

F Distal
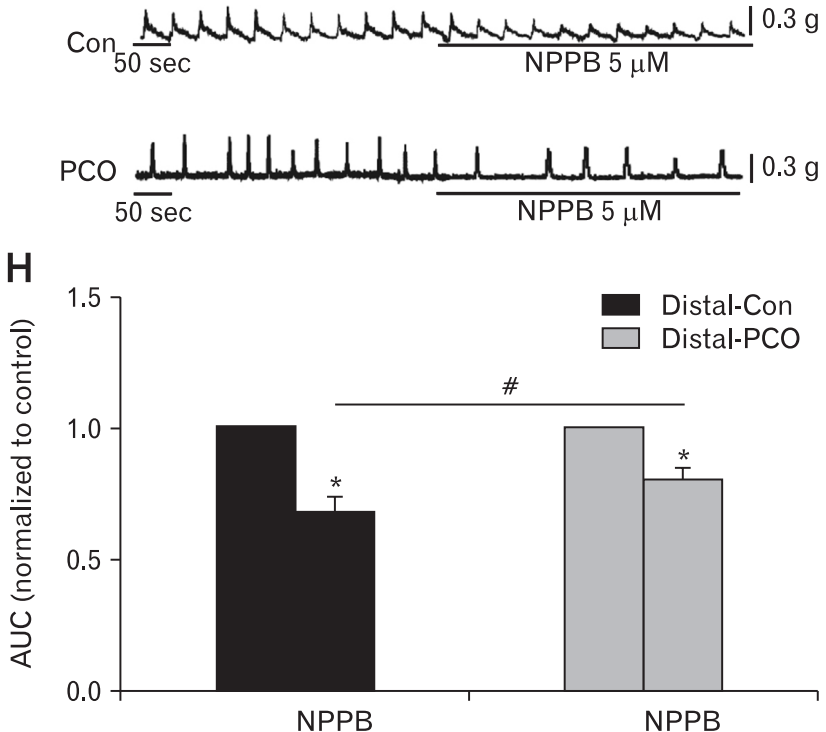

Figure 4. Contractile responses to inhibitors of nitric oxide synthase (NOS) and $\mathrm{Ca}^{2+}$-activated $\mathrm{Cl}^{-}$channel (Ano1) in the colonic muscles of control (Con) and partial colon obstruction (PCO) mice. (A, B) The inhibitory effects of NG-Nitro-l-arginine methyl ester hydrochloride (LNAME; $100 \mu \mathrm{M}$ ) on spontaneous contractions in the proximal and distal colons of both control and PCO mice. (C, D) Summary data shows the normalized area under the curve (AUC) in control and after the application of L-NAME ( $\mathrm{n}=5$; ${ }^{*} P<0.05$, control vs L-NAME; ${ }^{\#} P<0.05$, control vs PCO mice). (E, F) Response of colonic smooth muscle contractions to 5-Nitro-2-(3-phenylpropylamino) benzoic acid (NPPB; $5 \mu \mathrm{M}$ ) in the proximal and distal colon in both control and PCO mice. $(\mathrm{G}, \mathrm{H})$ Summary of the contractile responses to NPPB as indicated by the AUC in colonic muscles of control and PCO mice. The data were normalized to the control value (before the application of $\mathrm{NPPB})\left(\mathrm{n}=5\right.$; ${ }^{*}<<0.05$, NPPB vs control; ${ }^{\#} \mathrm{P}<0.05, \mathrm{PCO}$ vs control mice).

Fig. 5B and 5D). These results directly show that $\mathrm{PCO}$ mice have less density of ICCs and higher density of PDGFR $\alpha^{+}$cells in both proximal and distal colons.
The Effect of Apamin and CyPPA on Colonic Smooth Muscle

To investigate the functional alteration of SK3 channels in PDGFR $\alpha^{+}$cells, the effects of the SK agonist, CyPPA and antag- 

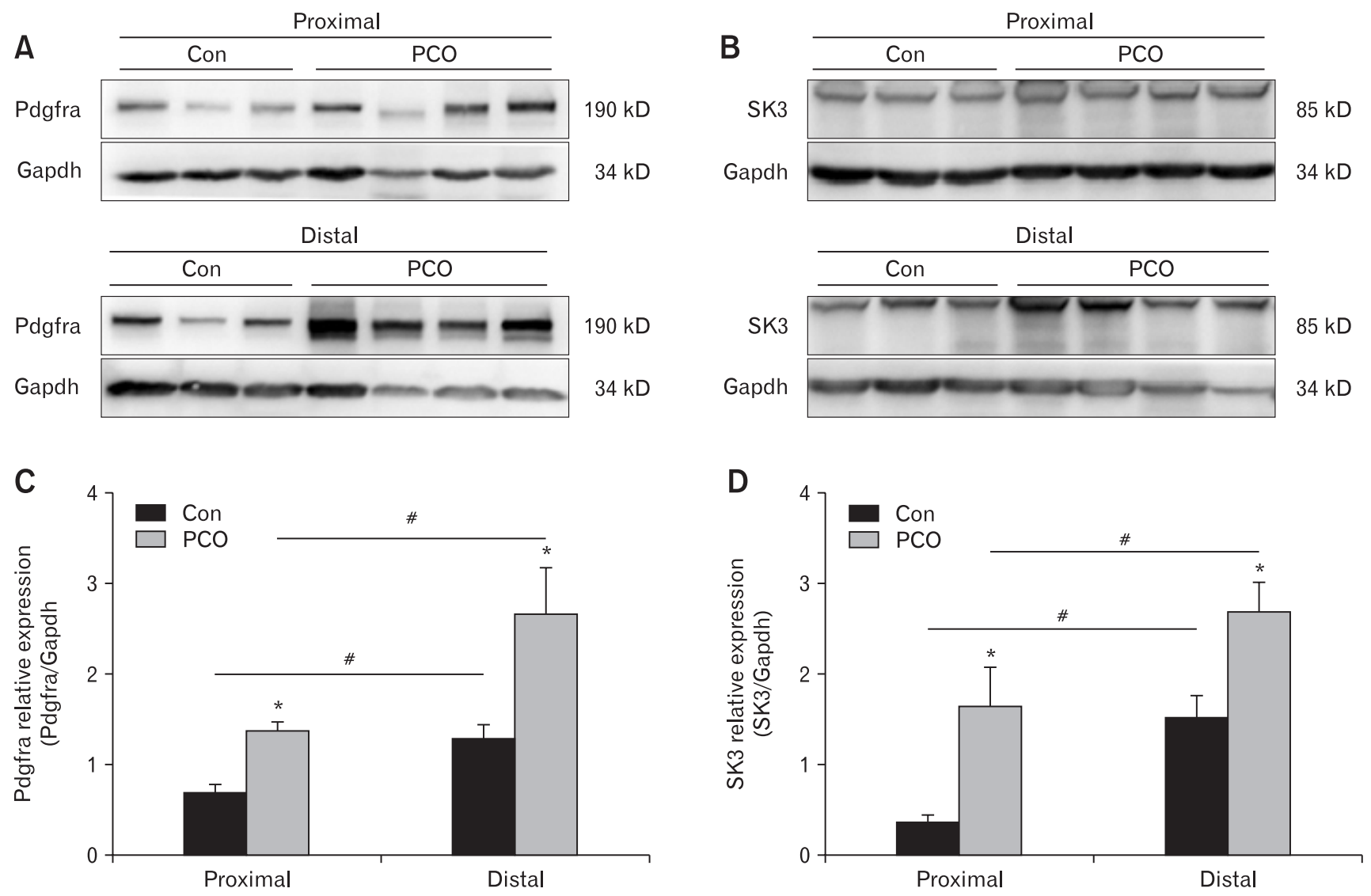

Figure 5. Western blot analysis of platelet-derived growth factor receptor- $\alpha$ (Pdgfra; A) and small conductance $\mathrm{Ca}^{2+}$-activated $\mathrm{K}^{+}$channel $3(\mathrm{SK} 3$; $\mathrm{B}$ ) in control (Con) and partial colon obstruction (PCO) mice. (C, D) The data were analyzed using densitometric quantification by Quantity One (\% glyceraldehyde-3-phosphate dehydrogenase [Gapdh], normalized to data from control mice; $\mathrm{n}=6$, ${ }^{\star} P<0.05$ vs control, ${ }^{\#} P<0.05$ proximal vs distal).

onist, apamin on CMMC and contractions of colonic muscle strips were observed.

In the proximal colon, CyPPA $(300 \mathrm{nM})$ reduced the AUC to $91.9 \pm 2.7 \%$ in control and $88.6 \pm 0.8 \%$ in $\mathrm{PCO}$ mice, respectively. These effects were significantly different in control and PCO $\left({ }^{\star} \mathrm{P}<0.05, \mathrm{n}=5\right.$; Fig. 6A-C). In the distal colon, CyPPA also decreased the AUC to $79.7 \pm 2.2 \%$ in control and to $36.1 \pm 5.3 \%$ in PCO mice. These effects were also different in control and PCO $\left({ }^{*} \mathrm{P}<0.05, \mathrm{n}=5\right.$; Fig. 6A, 6B, and 6D). The relaxation effect of the SK agonist was more obvious in the $\mathrm{PCO}$ murine colon $\left({ }^{\#} \mathrm{P}<\right.$ 0.05 in proximal colons, ${ }^{\#} P<0.05$ in distal colons, Fig. $6 \mathrm{C}$ and 6D). Apamin (300 $\mathrm{nM})$ enhanced the AUC of CMMC activity to $106.2 \pm 7.7 \%$ in control and $116.9 \pm 3.6 \%$ in $\mathrm{PCO}$ of the proximal colon $\left({ }^{*} \mathrm{P}<0.05, \mathrm{n}=5\right.$; Fig. $\left.6 \mathrm{E}-\mathrm{G}\right)$, and to $120.7 \pm 3.6 \%$ in control and $128.3 \pm 9.3 \%$ in $\mathrm{PCO}$ of the distal colon $\left({ }^{\star} \mathrm{P}<0.05\right.$, $\mathrm{n}=5$; Fig. $6 \mathrm{E}, 6 \mathrm{~F}$, and $6 \mathrm{H})$. The effects of apamin were more remarkable in the $\mathrm{PCO}$ mice $\left({ }^{\#} \mathrm{P}<0.05\right.$ in proximal colons, ${ }^{\#} \mathrm{P}<$
0.05 in distal colons; Fig. $6 \mathrm{G}$ and $6 \mathrm{H}$ ).

Isometric force measurements using colonic muscle strips were also performed to test effectiveness of $\mathrm{CyPPA}$ and apamin. CyPPA reduced the AUC of proximal colonic smooth muscle to $55.2 \pm$ $5.7 \%$ in control and $37.8 \pm 8.0 \%$ in $\mathrm{PCO}\left({ }^{*} \mathrm{P}<0.05, \mathrm{n}=5\right.$; Fig. $7 \mathrm{~A}$ and $7 \mathrm{C}$ ), respectively. In the distal colon, the AUC by CyPPA treatment were decreased to $33.3 \pm 3.2 \%$ in control and $16.3 \pm$ $7.9 \%$ in $\mathrm{PCO}\left({ }^{*} \mathrm{P}<0.05, \mathrm{n}=5\right.$; Fig. $7 \mathrm{~B}$ and $\left.7 \mathrm{D}\right)$. The $\mathrm{PCO}$ colonic strips were more sensitive to $\mathrm{CyPPA}$ compared with control mice $\left({ }^{\#} P<0.05\right.$ in proximal colons, ${ }^{\#} P<0.05$ in distal colons; Fig. $7 \mathrm{C}$ and $7 \mathrm{D})$. In control muscle strips, apamin enhanced to $123.9 \pm 5.9 \%$ in the proximal colon $\left({ }^{\star} \mathrm{P}<0.05, \mathrm{n}=5\right.$; Fig. $7 \mathrm{E}$ and $7 \mathrm{G})$ and $147.5 \pm 6.8 \%$ in the distal colon $\left({ }^{\star} \mathrm{P}<0.05, \mathrm{n}=5\right.$; Fig. $7 \mathrm{~F}$ and $7 \mathrm{H}$ ). Interestingly, in the $\mathrm{PCO}$ colon, apamin dramatically increased the AUC to $200.3 \pm 10.8 \%$ in proximal colon $\left({ }^{*} P\right.$ $<0.05, \mathrm{n}=5$; Fig. $7 \mathrm{E}$ and $7 \mathrm{G})$ and $196.8 \pm 29.2 \%$ in the distal colon $\left({ }^{*}<<0.05, \mathrm{n}=5\right.$; Fig. $7 \mathrm{~F}$ and $\left.\mathrm{H}\right)$. Murine colonic smooth 
A Con

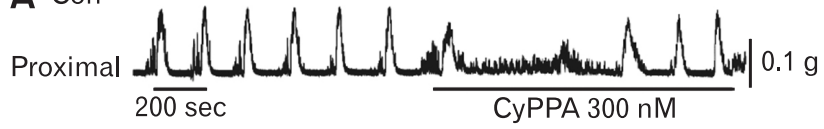

Distal $\left.{ }_{200 \mathrm{sec}}^{\Lambda} \Lambda_{\text {CyPPA } 300 \mathrm{nM}}\right|^{0.1 \mathrm{~g}}$

C

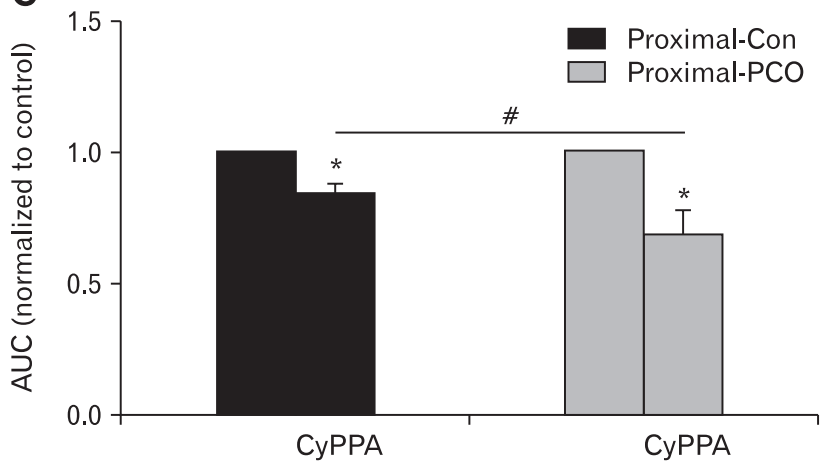

E Con
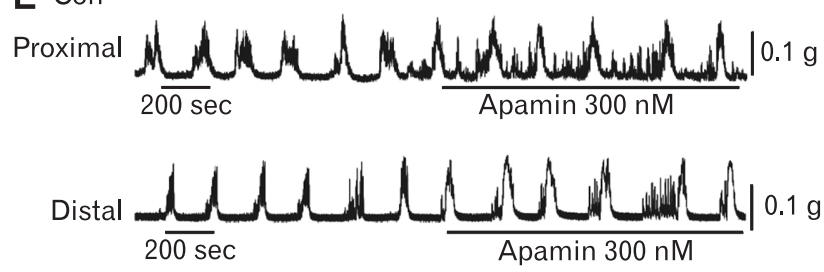

Proximal-Con

Proximal-PCO

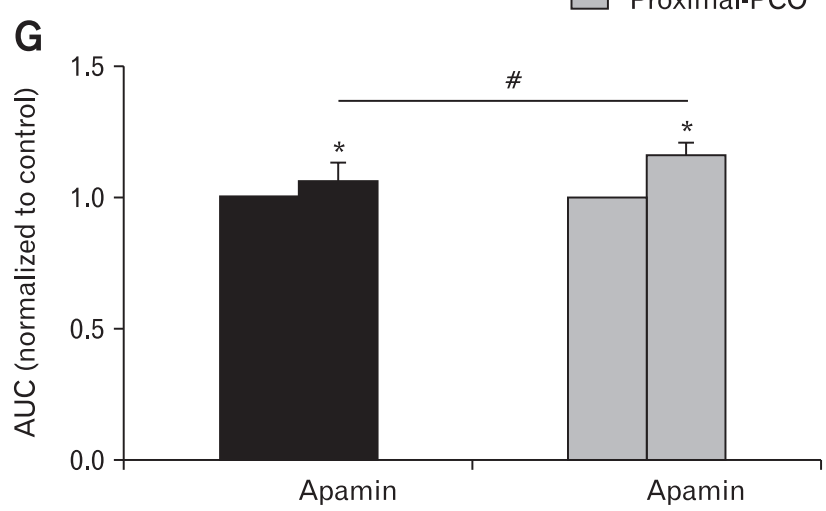

B PCO

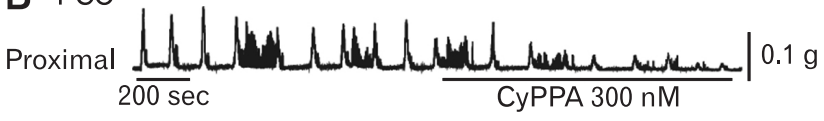

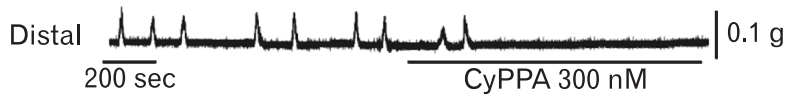

D

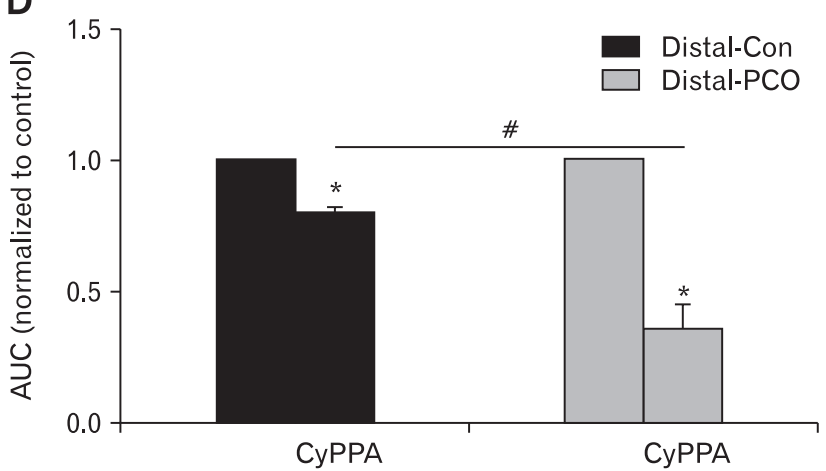

F PCO

${ }_{200 \mathrm{sec}} \frac{{ }_{\text {Proximal }}}{\text { Apamin } 300 \mathrm{nM}}$
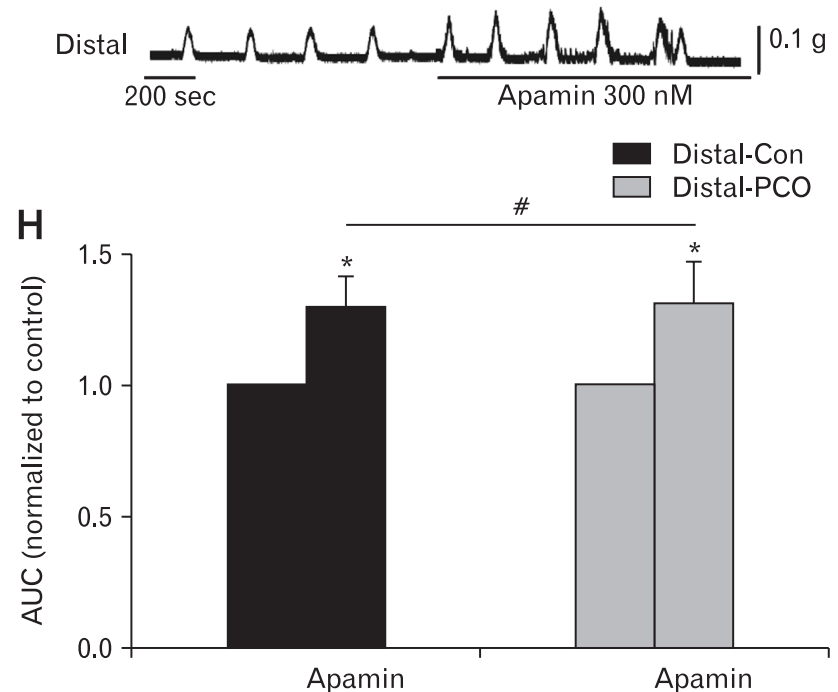

Figure 6. Response of colonic migrating motor complexes (CMMCs) to a small conductance $\mathrm{Ca}^{2+}$-activated $\mathrm{K}^{+}$channel (SK) agonist and antagonist in the colonic muscles of control (Con) and partial colon obstruction (PCO) mice. (A, B) The inhibitory effects of SK agonist, CyPPA (300 $\mathrm{nM}$ ), on CMMCs in the proximal and distal colons in both control and PCO mice. (C, D) Summary of the area under the curve (AUC) data shows the normalized values to the control (before the application of $\mathrm{CyPPA})\left(\mathrm{n}=5 ;{ }^{*} \mathrm{P}<0.05\right.$, CyPPA vs control; ${ }^{*} \mathrm{P}<0.05$, $\mathrm{PCO}$ vs control mice). (E, F) Response of CMMCs to apamin $(300 \mathrm{nM})$ in the proximal and distal colons in both control and PCO mice. (G, H) Summary of the CMMCs to apamin in colonic muscles from control and PCO mice. The data were normalized to the control value (before the application of apamin) $\left(\mathrm{n}=5 ;{ }^{*} \mathrm{P}<0.05\right.$, apamin vs control; ${ }^{*} \mathrm{P}<0.05, \mathrm{PCO}$ vs control mice). 
A Proximal

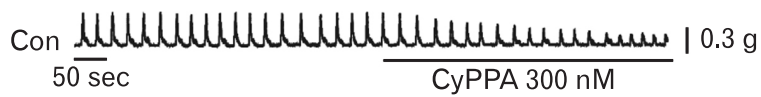

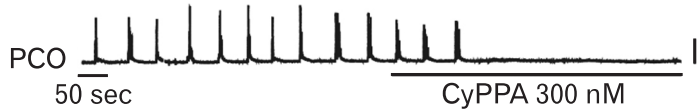

$10.3 \mathrm{~g}$

C

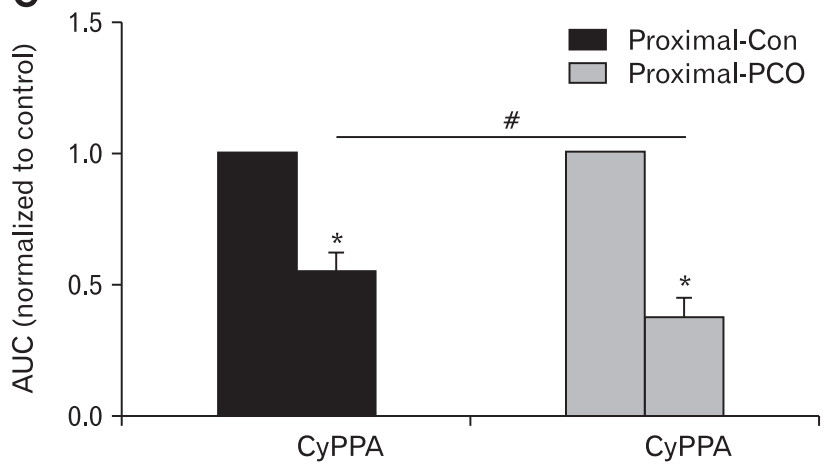

E Proximal
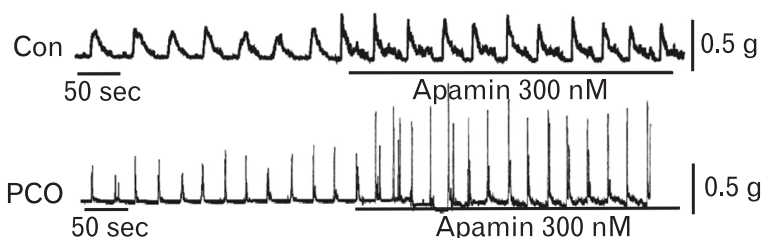

Proximal-Con

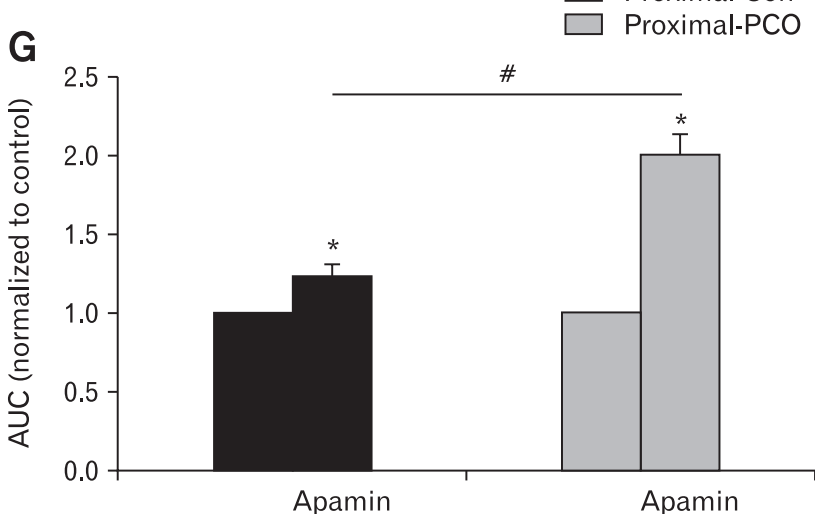

B Distal

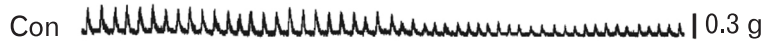
$50 \mathrm{sec} \quad$ CyPPA $300 \mathrm{nM}$
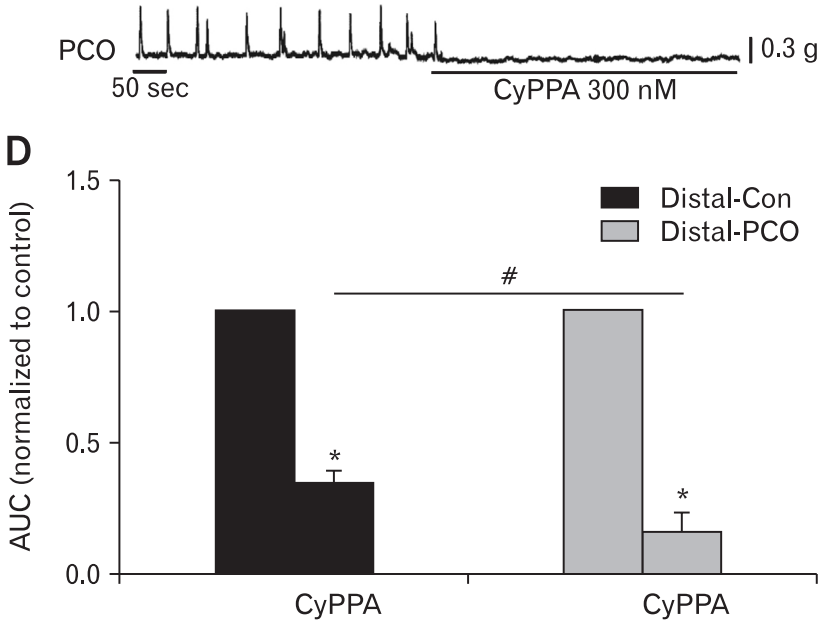

F Distal

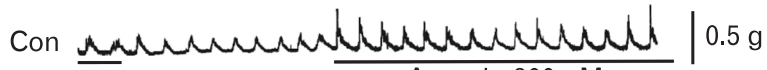
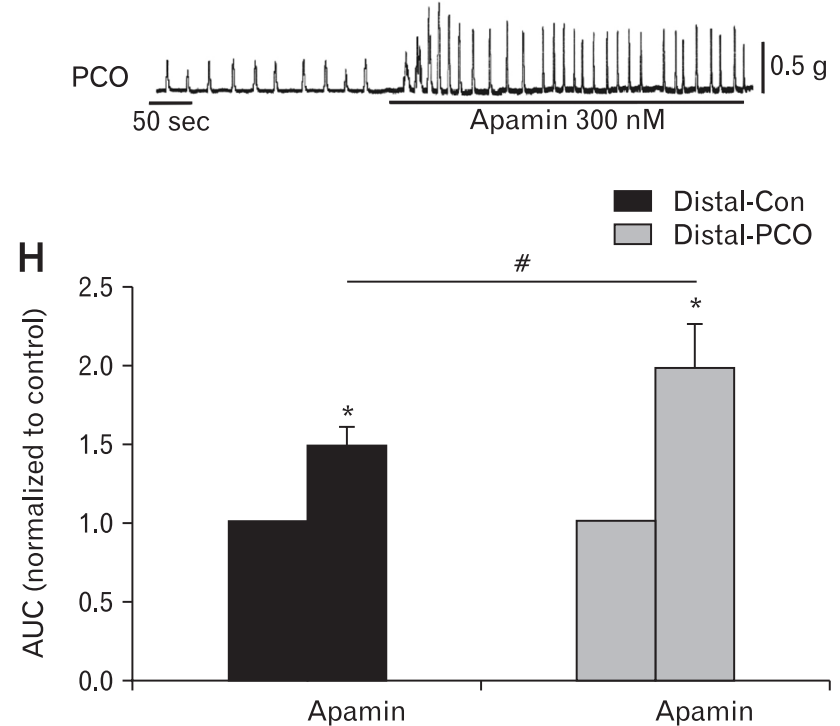

Figure 7. Contractile responses to the small conductance $\mathrm{Ca}^{2+}$-activated $\mathrm{K}^{+}$channel (SK) agonist and antagonist in the colonic muscles of control (Con) and partial colon obstruction (PCO) mice. (A, B) The inhibitory effects of SK agonist, CyPPA (300 nM), on spontaneous contractions in the proximal and distal colons in both control and PCO mice. (C, D) Summary of the area under the curve (AUC) in control and PCO. The data were normalized to the control (before the application of $\mathrm{CyPPA}$ ) ( $\mathrm{n}=5$; ${ }^{*} \mathrm{P}<0.05$, CyPPA vs control; ${ }^{\#} \mathrm{P}<0.05$, PCO vs control mice). (E, F) Response of colonic smooth muscle contractions to apamin $(300 \mathrm{nM})$ in the proximal and distal colon in both control and PCO mice. (G, $\mathrm{H})$ Summary of the contractile responses to apamin in the colonic muscles of control and PCO mice. The data were normalized to the control value (before the application of apamin) $\left(\mathrm{n}=5 ;{ }^{*} \mathrm{P}<0.05\right.$, apamin vs control; ${ }^{*} \mathrm{P}<0.05$, PCO vs control mice).

muscle in PCO showed greater effectiveness of apamin $\left({ }^{\#} \mathrm{P}<0.05\right.$ in proximal colons, ${ }^{\#} \mathrm{P}<0.05$ in distal colons; Fig. $7 \mathrm{G}$ and $7 \mathrm{H}$ ). According to these results, we suggest that PDGFR $\alpha^{+}$cells and SK3 channels may be upregulated in PCO mice in both the proxi- mal and distal colons. 


\section{Discussion}

PCO occurs on account of mechanical or functional obstruction. ${ }^{16,17}$ Mechanical obstruction happens due to a block of the intraluminal passage including adhesions, hernias, carcinoma and diverticulitis. ${ }^{18,19}$ Functional obstruction could be due to neuromuscular disorders such as Hirschsprung's disease. ${ }^{20-22}$ Mechanical and functional obstruction induces distended proximal colon in the obstruction site with accumulation of the feces and gas. ${ }^{23}$ The obstructed segments displayed altered motility and increased thickness of the smooth muscle layer. ${ }^{24,25}$ Besides the morphological changes in PCO, the pathophysiological mechanisms of colonic dysmotility in $\mathrm{PCO}$ are not known. ${ }^{18,19}$

A reliable PCO model had been established by using a silicon band around the distal colon wall through the mesentery in literature. ${ }^{26-28}$ In the present experiments, the silicon ring was placed at the end of distal colon. Feces were accumulated at the distal end of the colon from the obstructed lesion due to difficulty of feces to pass through the obstructed colonic segment. After surgery, the mice gradually developed abdominal distention. The mice were sacrificed 7 days after operation. H\&E staining showed muscle layer hypertrophy (Fig. 1). This PCO model was used to investigate the mechanism of colonic dysmotility.

Generation of CMMC is due to activation of the enteric nervous system that drives fecal pellets in an aboral direction. ${ }^{29} \mathrm{Ex}-$ citatory and inhibitory neurotransmitters affect the activity of ICC and induce CMMC via smooth muscle contractions in the intact colonic segment. In previous reports, a partial intestinal obstruction mouse model showed ICC remodeling. ${ }^{30,31}$ Loss of ICC could disrupt CMMC. The present data showed significant changes in the frequency of CMMC (decreased AUC) in PCO compared to controls.

To determine the relationship between ICCs and colonic dysmotility in PCO mice, we examined the expression of Kit and Ano1 proteins. Kit and Ano1 decreased significantly in the proximal ( $>2 \mathrm{~cm}$ from oral to obstructed lesion) and distal segment $(2 \mathrm{~cm}$ from oral to obstructed lesion) in PCO mice. In previous reports, loss or disruption of ICC networks was reported in an obstruction model. ${ }^{14}$ Furthermore, when ICCs in the small intestine were disrupted by the obstruction, the loss of pacemaker electrical activity and responses to neurotransmitters were observed. ${ }^{11}$ Ano1 channels in ICC are the main conductance to generate pacemaker activity. ${ }^{32}$ In the present study, we used NPPB, an Ano1 blocker to test functional changes of Ano1 in PCO. Colonic muscle strips were used for measuring spontaneous contractions. NPPB showed less effect in PCO than in control contractions. Similar responses were observed on CMMCs. These data suggest that PCO exhibited functional downregulation of Ano1 channels in ICC. The underlying mechanisms of downregulation of Kit and Ano1 in PCO are unknown.

ICC-IM in the colon are the main target cells of NO. NO is one dominating inhibitory neurotransmitter in the colon. ${ }^{33,34} \mathrm{We}$ tested the effect of the $\mathrm{NO}$ synthase inhibitor on the spontaneous contractions of smooth muscle and CMMCs in control and PCO mice. The results showed that contractions of colonic smooth muscle were enhanced after the addition of L-NAME in control colons. The effect of L-NAME was less sensitive in PCO compared to controls. This result could be due to downregulation of $\mathrm{nNOS}$ shown in colonic pseudo-obstruction, ${ }^{35}$ and downregulation of Kit based on the present findings.

PDGFR $\alpha^{+}$cells express SK3 protein. Inhibitory neurotransmitters, mainly purines bind to G-protein coupled P2Y1 receptors in PDGFR $\alpha^{+}$cells, ${ }^{4,936}$ increase intracellular $\mathrm{Ca}^{2+}$, activate SK3 channels, and induce hyperpolarization. ${ }^{37,38}$ In the present study, western blot displayed that the Pdgfra and SK3 proteins were significantly upregulated in PCO colon compared with those of control mice. We also tested the effects of SK channel agonist and antagonist on the spontaneous contractions of muscle strips from the proximal and distal colons in controls and PCO. The results showed that the SK agonist, CyPPA significantly decreased contractions in control colonic muscles. PCO colons were more sensitive to $\mathrm{CyPPA}$ compared to responses in control colonic muscles. Apamin, a SK antagonist increased the AUC of spontaneous contractions in controls. Moreover, apamin sensitivity was higher in PCO than in control colons. In CMMC, the effects of apamin were also significantly stronger in the PCO mice than in the normal control colons. Our data suggest that the upregulation of the Pdgfra and SK3 channels in the PCO colon induced significant inhibitory effects by SK agonist and excitatory effects by SK antagonist on muscle contractions and CMMCs. Mechanisms of gain or upregulation of Pdgfra and SK3 are not known. Understanding mechanisms of upregulation of these proteins will be an interesting future project.

In summary, PCO mice displayed different patterns of smooth muscle contractions and CMMCs. PCO mice exhibited colonic dysmotility due to downregulation of Kit and Ano1 channels, and upregulation of Pdgfra and SK3 channels. These data were supported by functional analysis. Spontaneous contractions and CMMCs were less sensitive to nNOS and Ano1 inhibitors but 
more sensitive to SK modulators in PCO colons. In conclusion, PCO leads to colonic dysmotility due to density changes in ICC and PDGFR $\alpha^{+}$cells and their subsequent changes in excitability.

Financial support: This study was supported by grants from Science and Technology Planning Project of Jiaxing City (No. 2018AY32019); Zhejiang Provincial Natural Science Foundation of China (No. LY20C11009); Research Fund for Lin He's Academician Workstation of New Medicine and Clinical Translation; and Science and Research Fund of Xinhua Hospital (No. 18YJ01XH2406).

\section{Conflicts of interest: None.}

Author contributions: Jie Chen was responsible for conception and design of the experiments; Xu Huang, Hongli Lu, and Wenxie $\mathrm{Xu}$ were responsible for the collection, analysis, and interpretation of data; Qianqian Wang and Jingyu Zang performed specific experimental tasks; Qianqian Wang drafted the article; and Jie Chen revised the manuscript critically for important intellectual content. All authors signed and approved the final submission.

\section{References}

1. Horiguchi K, Komuro T. Ultrastructural observations of fibroblast-like cells forming gap junctions in the $\mathrm{W} / \mathrm{W}(\mathrm{nu})$ mouse small intestine. J Auton Nerv Syst 2000;80:142-147.

2. Iino S, Horiguchi K, Horiguchi S, Nojyo Y. c-Kit-negative fibroblastlike cells express platelet-derived growth factor receptor alpha in the murine gastrointestinal musculature. Histochem Cell Biol 2009;131:691702.

3. Koh SD, Ward SM, Sanders KM. Ionic conductances regulating the excitability of colonic smooth muscles. Neurogastroenterol Motil 2012;24:705-718

4. Sung TS, Hwang SJ, Koh SD, et al. The cells and conductance mediating cholinergic neurotransmission in the murine proximal stomach. J Physiol 2018;596:1549-1574.

5. Blair PJ, Rhee PL, Sanders KM, Ward SM. The significance of interstitial cells in neurogastroenterology. J Neurogastroenterol Motil 2014;20:294-317.

6. Ward SM, Sanders KM. Involvement of intramuscular interstitial cells of Cajal in neuroeffector transmission in the gastrointestinal tract. J Physiol 2006;576:675-682.

7. Kurahashi M, Zheng H, Dwyer L, Ward SM, Koh SD, Sanders KM. A functional role for the 'fibroblast-like cells' in gastrointestinal smooth muscles. J Physiol 2011;589(Pt 3):697-710.

8. Jiménez M. Platelet-derived growth factor receptor-alpha-positive cells: new players in nerve-mediated purinergic responses in the colon. J Physiol 2015;593:1765-1766.
9. Koh SD, Rhee PL. Ionic conductance(s) in response to post-junctional potentials. J Neurogastroenterol Motil 2013;19:426-432.

10. Lu C, Huang X, Lu HL, et al. Different distributions of interstitial cells of Cajal and platelet-derived growth factor receptor-alpha positive cells in colonic smooth muscle cell/interstitial cell of Cajal/platelet-derived growth factor receptor-alpha positive cell syncytium in mice. World J Gastroenterol 2018;24:4989-5004.

11. Chang IY, Glasgow NJ, Takayama I, Horiguchi K, Sanders KM, Ward SM. Loss of interstitial cells of Cajal and development of electrical dysfunction in murine small bowel obstruction. J Physiol 2001;536(Pt 2):555-568.

12. Fintl C, Hudson NP, Mayhew IG, Edwards GB, Proudman CJ, Pearson GT. Interstitial cells of Cajal (ICC) in equine colic: an immunohistochemical study of horses with obstructive disorders of the small and large intestines. Equine Vet J 2004;36:474-479.

13. Wu B, Liu L, Gao H, et al. Distribution of interstitial cells of Cajal in Meriones unguiculatus and alterations in the development of incomplete intestinal obstruction. Histol Histopathol 2013;28:1567-1575.

14. Becheanu G, Manuc M, Dumbravă M, Herlea V, Hortopan M, Costache M. The evaluation of interstitial Cajal cells distribution in nontumoral colon disorders. Rom J Morphol Embryol 2008;49:351-355.

15. Wu CC, Lin YM, Gao J, Winston JH, Cheng LK, Shi XZ. Are interstitial cells of Cajal involved in mechanical stress-induced gene expression and impairment of smooth muscle contractility in bowel obstruction? PLoS One 2013;8:e76222.

16. Summers RW, Lu CC. Approach to the patient with ileus and obstruction. In: Yamada T, Alpers DH, Laine L, Kaplowitz N, Owyang C, Powell DW ed. Textbook of Gastroenterology. Volume 1. 1st ed. Philadelphia: Saunders 1999:842-858.

17. Welch JP. Bowel obstruction: differential diagnosis and clinical management. 1st ed. Philadelphia: Saunders 1990:59-95.

18. Cappell MS, Batke M. Mechanical obstruction of the small bowel and colon. Med Clin North Am 2008;92:575-597.

19. Rami Reddy SR, Cappell MS. A systematic review of the clinical presentation, diagnosis, and treatment of small bowel obstruction. Curr Gastroenterol Rep 2017;19:28.

20. De Giorgio R, Cogliandro RF, Barbara G, Corinaldesi R, Stanghellini $\mathrm{V}$. Chronic intestinal pseudo-obstruction: clinical features, diagnosis, and therapy. Gastroenterol Clin North Am 2011;40:787-807.

21. Wells CI, O'Grady G, Bissett IP. Acute colonic pseudo-obstruction: a systematic review of aetiology and mechanisms. World J Gastroenterol 2017;23:5634-5644.

22. Heuckeroth RO. Hirschsprung disease - integrating basic science and clinical medicine to improve outcomes. Nat Rev Gastroenterol Hepatol 2018;15:152-167.

23. Jacobs DO. Acute intestinal obstruction. In: Jameson J, Fauci AS, Kasper DL, Hauser SL, Longo DL, Loscalzo J, eds. Harrison's principles of internal medicine. Vol 10. 20th ed. New York: McGraw-Hill 2014:323.

24. Bertoni S, Gabella G, Ghizzardi P, et al. Motor response of rat hypertrophic intestine following chronic obstruction. Neurogastroenterol Motil 2004;16:365-374.

25. Won KJ, Suzuki T, Hori M, Ozaki H. Motility disorder in experi- 
mentally obstructed intestine: relationship between muscularis inflammation and disruption of the ICC network. Neurogastroenterol Motil 2006;18:53-61.

26. Shi XZ, Lin YM, Powell DW, Sarna SK. Pathophysiology of motility dysfunction in bowel obstruction: role of stretch induced COX-2. Am J Physiol Gastrointest Liver Physiol 2011;300:G99-G108.

27. Lin YM., Sarna SK, Shi XZ. Prophylactic and therapeutic benefits of COX-2 inhibitor on motility dysfunction in bowel obstruction: roles of $\mathrm{PGE}_{2}$ and EP receptors. Am J Physiol Gastrointest Liver Physiol 2012;302:G267-G275.

28. Lin YM, Fu Y, Winston J, et al. Pathogenesis of abdominal pain in bowel obstruction: role of mechanical stress-induced upregulation of nerve growth factor in gut smooth muscle cells. Pain 2012;158:583-592.

29. Heredia DJ, Dickson EJ, Bayguinov PO, Henning GW, Smith TK. Localized release of serotonin (5-hydroxytryptamine) by a fecal pellet regulates migrating motor complexes in murine colon. Gastroenterology 2009;136:1328-1338.

30. Liu DH, Huang X, Guo X, et al. Voltage dependent potassium channel remodeling in murine intestinal smooth muscle hypertrophy induced by partial obstruction. PLoS One 2014;9:e86109.

31. Yang J, Zhao J, Chen P, Nakaguchi T, Grundy D, Gregersen H. Interdependency between mechanical parameters and afferent nerve discharge in hypertrophic intestine of rats. Am J Physiol Gastrointest Liver Physiol
2016;310:G376-G386.

32. Zhu MH, Kim TW, Ro S, et al. $\mathrm{A} \mathrm{Ca}^{2+}$-activated $\mathrm{Cl}^{-}$conductance in interstitial cells of Cajal linked to slow wave currents and pacemaker activity. J Physiol 2009;587(Pt 20):4905-4918.

33. Suzuki H, Ward SM, Bayguinov YR, Edwards FR, Hirst GD. Involvement of intramuscular interstitial cells in nitrergic inhibition in the mouse gastric antrum. J Physiol 2003;546:751-763.

34. Ward SM, Sanders KM. Physiology and pathophysiology of the interstitial cell of Cajal: from bench to bedside. I. Functional development and plasticity of interstitial cells of Cajal networks. Am J Physiol Gastrointest Liver Physiol 2001;281:G602-G611.

35. Do YS, Myung SJ, Kwak SY, et al. Molecular and cellular characteristics of the colonic pseudo-obstruction in patients with intractable constipation. J Neurogastroenterol Motil 2015;21:560-570.

36. Song NN, Lu HL, Lu C, et al. Diabetes-induced colonic slow transit mediated by the up-regulation of PDGFR $\alpha^{+}$cells/SK3 in streptozotocin-induced diabetic mice. Neurogastroenterol Motil Published Online First: 9 Mar 2018. doi: 10.1111/nmo. 13326.

37. Baker SA, Hennig GW, Salter AK, Kurahashi M, Ward SM, Sanders KM. Distribution and $\mathrm{Ca}^{2+}$ signalling of fibroblast-like $\left(\mathrm{PDGFR}^{+}\right)$cells in the murine gastric fundus. J Physiol 2013;591:6193-6208.

38. Sanders KM, Ward SM, Koh SD. Interstitial cells: regulators of smooth muscle function. Physiol Rev 2014;94:859-907. 